\title{
PENGARUH PAPARAN MEDAN ELEKTROMAGNETIK FREKUENSI RADIO 1800 MHZ TERHADAP PERSENTASE SEL T CD4+ PADA KULTUR PERIPHERAL BLOOD MONONUCLEAR CELLS
}

\author{
Fara Felisa Putri ${ }^{\star 凶}$, Novi Khila Firani**, Rahmad ${ }^{\star \star \star}$, Maimun Zulhaidah Arthamin ${ }^{\star \star \star}$
}

\begin{abstract}
Abstrak
Penggunaan gelombang elektromagnetik telah banyak dijumpai dalam kehidupan sehari-hari, salah satunya gelombang elektromagnetik global system for mobile communication (GSM) pada ponsel. Beberapa penelitian menyebutkan paparan medan elektromagnetik pada ponsel dapat mempengaruhi fungsi sel dalam tubuh, antara lain sel limfosit. Penelitian ini dilakukan untuk mengetahui pengaruh paparan medan elektromagnetik $1800 \mathrm{Mhz}$ terhadap persentase sel limfosit T CD4+ pada kultur peripheral blood mononuclear cells (PBMC). Penelitian ini menggunakan metode experimental design di laboratorium Biomedik dan Parasitologi Klinik, Fakultas Kedokteran, Universitas Brawijaya secara in vitro dengan pre \& post test group design pada kultur PBMC pada kelompok sampel yang telah dipapar dengan medan elektromagnetik frekuensi radio $1800 \mathrm{Mhz}$ selama 60 menit dengan jarak $5 \mathrm{~cm}$. Analisis sampel dilakukan dengan FACSVia flowsitometer untuk menganalisis persentase limfosit T CD4+. Analisis data dilakukan dengan uji normalitas, uji homogenitas, dan uji Wilcoxon. Hasilnya didapatkan rata-rata persentase sel limfosit T CD4+ sebelum paparan $38,765 \% \pm 8,42$ dan setelah paparan meningkat menjadi $42,545 \% \pm 2,33$. Namun peningkatan yang terjadi masih dalam batas normal dan tidak berbeda signifikan. Hasil penelitian menyimpulkan bahwa paparan gelombang elektromagnetik $1800 \mathrm{Mhz}$ selama 60 menit pada jarak $5 \mathrm{~cm}$ tidak mempengaruhi persentase sel T CD4 pada kultur PBMC.
\end{abstract}

Kata kunci: limfosit, medan elektromagnetik $1800 \mathrm{MHz}$, peripheral blood mononuclear cells (PBMC), sel T $\mathrm{CD} 4+$

\section{THE EFFECT OF 1800 MHZ RADIO FREQUENCY ELECTROMAGNETIC FIELD ON PERCENTAGE OF CD4+ T CELLS IN PERIPHERAL BLOOD MONONUCLEAR CELLS}

\begin{abstract}
The use of electromagnetic waves has been widely encountered in everyday life, one of which is the global system for mobile communication (GSM) electromagnetic waves on cell phones. Several studies have stated that exposure to electromagnetic fields on cell phones can affect the function of cells in the body, including lymphocytes. This research was conducted to identify the effect of $1800 \mathrm{Mhz}$ electromagnetic field on the percentage of CD4 + T lymphocytes in peripheral blood mononuclear cells (PBMC) cultures. This research used experimental design method in the Biomedic and Clinical Parasitology Laboratory, Faculty of Medicine, Universitas Brawijaya in vitro with pre \& post test group design on PBMC culture in the sample group that was exposed to an electromagnetic field radio frequency $1800 \mathrm{Mhz}$ for 60 minutes with a distance of $5 \mathrm{~cm}$. Sample analysis was performed with a FACSVia flowcytometer to know the percentage of CD4 + T lymphocytes. Data analysis was performed using the normality test, homogeneity test, and Wilcoxon test. The results showed that the average percentage of CD4 + T lymphocyte cells before exposure was $38.765 \%$ \pm 8.42 and after exposure increased to $42.545 \% \pm 2.33$, but the increase was still within normal range and did not differ significantly. It can be concluded that exposure to electromagnetic waves of $1800 \mathrm{Mhz}$ for 60 minutes at a distance of $5 \mathrm{~cm}$ does not change the percentage of CD4 T cells in PBMC culture.
\end{abstract}

Keywords: CD4+ T cell, 1800 Mhz electromagnetic field, lymphocyte, peripheral blood mononuclear cells (PBMC)

\footnotetext{
${ }^{*}$ Program Studi (S1) Kedokteran, Fakultas Kedokteran, Universitas Brawijaya

${ }^{*}$ Departemen Biokimia Biomolekular, Fakultas Kedokteran, Universitas Brawijaya

***Departemen Rehabilitasi Medik, Fakultas Kedokteran, Universitas Brawijaya

Departemen Patologi Klinik, Fakultas Kedokteran, Universitas Brawijaya

E-mail: farafelisa@student.ub.ac.id
} 


\section{Pendahuluan}

Pada tahun 2018 lembaga riset digital marketing Emarketer memperkirakan sekitar 100 juta orang di Indonesia aktif menggunakan ponsel. Hal ini menjadikan Indonesia sebagai negara dengan pengguna aktif ponsel terbesar ke-4 di dunia setelah Cina, India, dan Amerika. Gelombang elektromagnetik pada ponsel berpotensi meningkatkan risiko yang berbahaya bagi kesehatan manusia salah satunya dengan mempengaruhi fungsi sel limfosit. ${ }^{1}$

Gelombang elektromagnetik global system for mobile communication (GSM) pada ponsel berkisar pada 1800 Mhz yang merupakan gelombang elektromagnetik frekuensi radio. Paparan gelombang elektromagnetik 1800 Mhz dalam waktu 60 menit menyebabkan peningkatan jumlah sel limfosit yang signifikan pada mencit. Peningkatan jumlah sel limfosit disebut dengan lomfositosis, sedangkan penurunan jumlah sel limfosit disebut dengan limfositopenia. ${ }^{2,3}$

Limfosit merupakan sel penting dalam sistem imun tubuh yang memberikan pertahanan terhadap antigen ekstraseluler dan intraseluler. Limfosit terdiri atas 3 jenis yaitu sel B, sel T dan sel Natural Killer (NK). ${ }^{3}$ Sel limfosit $T$ dibedakan menurut protein permukaan yang diidentifikasikasi melalui standar nomenklatur $\mathrm{CD}$ atau Cluster of Differentiation sebagai sel T CD4+ dan sel $\mathrm{T}$ CD8+. Sel T CD4+ dapat memberikan sinyal kepada sel B untuk memproduksi antibodi dan membantu sel fagosit dalam menghancurkan mikroba. Mekanisme inilah yang mendasari sel T CD4+ disebut juga dengan sel $T$ helper. Profil sel T CD4+ seseorang dapat diketahui tanpa me-nimbulkan risiko terjadinya masalah etik pada manusia dan hewan coba dengan menganalisis kultur peripheral blood mononuclear cells (PBMC). 4,5

Paparan medan elektromagnetik 1800 Mhz selama 60 menit terhadap limfosit $T$
CD4+ dengan atau tanpa stimulasi mitogenik pada donor muda dan lanjut usia menunjukkan adanya pengaruh pada individu lanjut usia. Didapatkan downregulation ekspresi CD95 di limfosit T CD4+ yang distimulasi dari pendonor lansia, namun tidak ditemukan downregulation pada pendonor muda. Penemuan ini menunjukkan bahwa kerentanan sel limfosit selain bergantung pada jarak dan waktu pemaparan juga bergantung pada usia. ${ }^{6}$

Untuk mengetahui apakah paparan medan elektromagnetik frekuensi radio 1800 Mhz mempengaruhi pertahanan tubuh manusia dalam hal ini sel limfosit T CD4+ maka dilakukan penelitian dengan melakukan pemaparan medan elektromagnetik $1800 \mathrm{Mhz}$ pada jarak $5 \mathrm{~cm}$ selama 60 menit terhadap persentase sel T CD4+ pada kultur peripheral blood mononuclear cells (PBMC) dari individu berusia muda yaitu $18-22$ tahun.

\section{Bahan dan Metode}

Penelitian ini merupakan penelitian eksperimental murni yang dilakukan di laboratorium Biomedik dan Parasitologi Klinik, Fakultas Kedokteran, Universitas Brawijaya secara in vitro dengan pre and post test group design pada kultur peripheral blood mononuclear cell (PBMC) pada kelompok sampel yang dipapar dengan medan elektromagnetik frekuensi radio $1800 \mathrm{Mhz}$ selama 60 menit dengan jarak $5 \mathrm{~cm}$. Pada penelitian ini dievaluasi efek paparan akut terhadap medan elektromagnetik pada persentase sel T CD4+. Penelitian ini telah mendapatkan persetujuan laik etik dari Komisi Etik Penelitian Kesehatan RSUD dr. Saiful Anwar Malang dengan nomer surat 146/EC/ KEPK/05/2019.

Populasi penelitian yang digunakan adalah populasi orang sehat. Sampel penelitian adalah kultur PBMC yang diambil dari darah orang sehat usia 18-22 tahun yang memenuhi kriteria inklusi dan eksklusi. 
Jumlah sampel yang digunakan sesuai dengan perhitungan rumus Federer didapatkan nilai $n$ sebesar 8,5 secara keseluruhan sampel yang dibutuhkan sebanyak 9 sampel pada penelitian ini digunakan 10 sampel. Sampel darah yang didapatkan dari Lab Sentral RSUD. dr. Saiful Anwar Malang kemudian dilakukan isolasi PBMC menggunakan Ficoll-Hipaque untuk memisahkan antara sel darah merah, plasma, dan PBMC. Kemudian PBMC yang sudah terisolasi dibagi menjadi 2 kelompok sampel yaitu sampel PBMC sebelum paparan dan setelah paparan medan elektromagnetik frekuensi radio $1800 \mathrm{MHz}$. Paparan medan elektromagnetik frekuensi radio $1800 \mathrm{MHz}$ didapatkan dari generator sinyal vektor VSG25A yang diatur menggunakan aplikasi VSG25A.exe dari laptop. Paparan medan elektromagnetik dilakukan dalam kotak paparan dengan jarak alat paparan dengan sampel sebesar $5 \mathrm{~cm}$ selama 60 menit. Suhu diatur dengan menggunakan termostat dan lampu pijar. Thermostat digunakan untuk melihat perubahan suhu dan lampu pijar untuk meningkatkan suhu sehingga bisa sesuai dengan lingkungan tubuh yaitu pada suhu $37^{\circ} \mathrm{C}$.
Kultur PBMC yang sudah dipapar dengan medan elektromagnetik dan kultur PBMC yang tidak mendapatkan paparan akan dilakukan pengecatan pewarnaan dengan antigen permukaan Cluster of Differentiation (CD) dengan fluokrom. Selanjutnya, persentase sel T CD4+ akan dianalisis dengan FACSVia flowsitometer (Becton Dickinson, San Jose, California, USA) dan selanjutnya analisis dilakukan dengan FACs Cell Quest software (BD Biosciences).

Analisis data yang digunakan untuk jumlah neutrofil menggunakan uji normalitas Shapiro Wilk, uji homogenitas dengan metode Levene, dan uji Wilcoxon.

\section{Hasil}

Hasil penelitian dianalisis secara deskriptif untuk mengetahui persentase sel T $\mathrm{CD} 4+$ sebelum paparan dan setelah paparan medan elektromagnetik $1800 \mathrm{Mhz}$, rata-rata dan standar deviasinya yang ditampilkan pada Tabel 1. Hasil mendapatkan peningkatan rata-rata persentase sel T CD4+ pada sampel sebelum paparan yaitu $38,765 \%$ $\pm 8,42$ dan rata-rata persentase sel T CD4+ setelah paparan yaitu $42,545 \% \pm 2,33$

Tabel 1. Persentase sel T CD4+ sebelum dan setelah paparan medan elektromagnetik frekuensi radio $1800 \mathrm{Mhz}$

\begin{tabular}{ccc}
\hline Sampel Normal & Sebelum Paparan (\%) & Setelah Paparan (\%) \\
\hline 1 & 32,81 & 40,9 \\
2 & 38,10 & 36,01 \\
3 & 42,3 & 35,63 \\
4 & 32,56 & 40,88 \\
5 & 32,44 & 41,76 \\
6 & 37,49 & 35,54 \\
7 & 40,9 & 35,61 \\
8 & 38,12 & 42,45 \\
9 & 40,57 & 43,57 \\
10 & 44,72 & 44,19 \\
\hline Rata - rata \pm SD & $38,765 \pm 8,42$ & $42,545 \pm 2,33$ \\
\hline
\end{tabular}


Syarat uji parametrik pada penelitian ini tidak terpenuhi karena data nilai yang telah diuji tidak terdistribusi secara normal, sehingga pengujian hipotesis menggunakan pengujian nonparametrik yaitu uji Wilcoxon. Uji Wilcoxon didapatkan 5 sampel mengalami penurunan persentase sel T CD4+ setelah dilakukan pemaparan dengan penurunan rata -rata sebesar 4,0 sedangkan, 5 sampel lainnya mengalami peningkatan persentase sel T CD4+ dengan peningkatan rata-rata sebesar 6,50. Uji signifikasi Wilcoxon didapatkan hasil 0,241 yang berarti $p>0,05$, sehingga tidak ada perbedaan yang signifikan antara persentase sel $\mathrm{T}$ CD4+ sebelum paparan dan setelah paparan medan elektromagnetik $1800 \mathrm{Mhz}$ dengan jarak $5 \mathrm{~cm}$ selama 60 menit. Hasil persentase sel $\mathrm{T}$ CD4+ sebelum dan setelah paparan yang dianalisis dengan FACSVia flowsitometer ditampilkan pada Gambar 1 dan Gambar 2.

- PLOTS

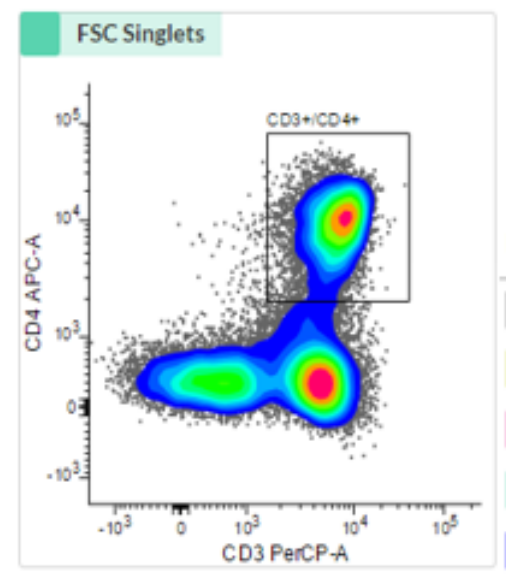

- STATISTICS

\begin{tabular}{|lll|}
\hline Population & Events $*$ & \% Parent * \\
\hline All Events & 42,722 & \\
\hline Scatter & 29,430 & $68.89 \%$ \\
\hline SSC Singlets & 29,378 & $99,82 \%$ \\
\hline FSC Singlets & 29,373 & $99.98 \%$ \\
\hline CD3+/CD4+ & 9,638 & $32.81 \%$ \\
\hline
\end{tabular}

Gambar 1. Analisis sel T CD4+ sebelum paparan medan elektromagnetik 1800 Mhz dengan FACSVia flowsitometer

Keterangan : Populasi CD3+/CD4+ menunjukkan persentase sel T CD4+ sebesar $32,81 \%$ sebelum papapran medan elektromagnetik $1800 \mathrm{MHz}$

\section{PLOTS}

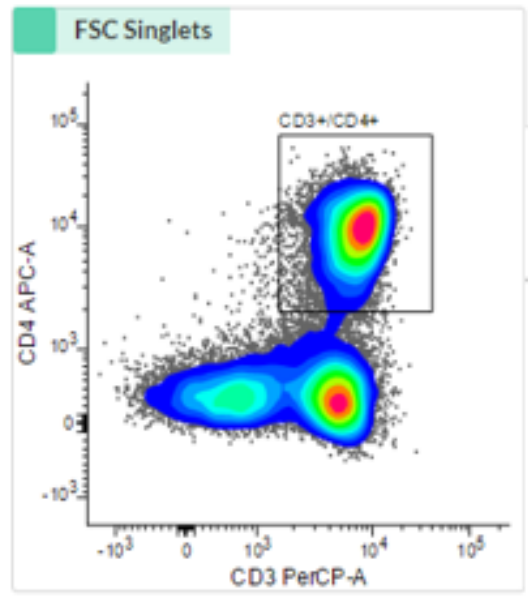

- STATISTICS

\begin{tabular}{|c|c|c|}
\hline Population & Events $*$ & \%Parent 8 \\
\hline All Events & 41,279 & \\
\hline Scatter & 24,106 & $58.40 \%$ \\
\hline SSC Singlets & 24,068 & $99.84 \%$ \\
\hline FSC Singlets & 24,060 & $99.97 \%$ \\
\hline $\mathrm{CD} 3+/ \mathrm{CD} 4+$ & 9,841 & $40.90 \%$ \\
\hline
\end{tabular}

Gambar 2. Analisis sel T CD4+ setelah paparan medan elektromagnetik 1800 Mhz dengan FACSVia flowsitometer Keterangan : Populasi CD3+/CD4+ menunjukkan persentase sel T CD4+ sebesar 40,90\% setelah papapran medan elektromagnetik $1800 \mathrm{MHz}$ 


\section{Pembahasan}

Setelah pemaparan didapatkan 5 individu mengalami penurunan persentase sel T CD4+, sedangkan 5 individu lainnya mengalami peningkatan persentase sel $T$ CD4+. Rata-rata persentase sel T CD4+ meningkat yaitu $38,77 \%$ pada sampel sebelum pemaparan dan $42,55 \%$ pada sampel setelah pemaparan, namun peningkatan ini masih dalam batas normal mengingat persentase sel $\mathrm{T}$ CD4+ normal adalah 30-60\% (Tabel 1).

Peristiwa peningkatan persentase sel $\mathrm{T}$ CD4+ diduga akibat dari adanya peningkatan respons imun terhadap radiasi. Peningkatan terjadi apabila ada benda asing atau bahan asing yang masuk ke dalam tubuh dalam hal ini adalah medan elektromagnetik $1800 \mathrm{Mhz}$. Selain itu, radiasi juga memicu terbentuknya radikal bebas. Sel $\mathrm{T} C D 4+$ yang beredar di dalam pembuluh darah perifer adalah sel $T$ CD4+ naif. Sel T CD4+ naif memerlukan sinyal dari antigen untuk berproliferasi dan berdiferensiasi menjadi sel efektor. Sel efektor $\mathrm{T}$ CD4+ atau sel $\mathrm{T}$ helper memproduksi protein yang disebut sitokin yang berfungsi untuk memberantas antigen. Ketika kadar radikal bebas yang terbentuk lebih besar dibandingkan antioksidan yang ada maka akan terbentuk stres oksidatif. Stres oksidatif akan memicu sel $\mathrm{T}$ CD4+ dalam jalur persinyalan pertumbuhan, sehingga pada flowsitomeri didapatkan persentase sel $T$ CD4+ mengalami peningkatan. $2,4,7$

Peristiwa penurunan persentase sel T diduga diakibatkan oleh peristiwa apopotosis atau nekrosis dari sel T CD4+. Ketika limfosit T CD4+ sudah berada pada titik puncak respons imun atau suatu rangsangan antigen sudah dibersihkan, maka untuk menjaga homeostasis atau keseimbangan sistem imun sel yang semula berpriliferasi kini tidak memiliki sinyal kelangsungan hidup akibatnya sel akan mati oleh apoptosis. Apoptosis atau kematian sel secara terprogram akan diaktifkan dan menyebabkan penurunan persentase sel T CD $4+.4$

Mekanisme lain adalah adanya jalur kematian sel berupa nekrosis. Nekrosis merupakan proses kematian sel secara tidak terkontrol sebagai akibat dari kerusakan sel akut yang disebabkan karena adanya stimulus yang bersifat patologis. Stimulus patologis ini dapat berupa kekurangan oksigen dalam sel, adanya perubahan suhu yang ekstrim, radiasi, dan trauma. Medan elektromagnetik $1800 \mathrm{Mhz}$ memberikan efek nonthermal yang menyebabkan peningkatan radikal bebas. Peningkatan radikal bebas yang terbentuk mengakibatkan kerusakan biologi terutama kerusakan DNA. Kerusakan DNA sel yang tidak dapat diperbaiki menyebabkan terjadinya kematian sel sehingga persentase sel mengalami pe-nurunan. 8,9

Menurut studi sebelumnya, terdapat hubungan antara paparan medan elektromagnetik 1800 Mhz dengan peningkatan diameter pulpa putih dan sel limfosit pada mencit setelah dilakukan pemaparan \pm 120 menit per hari selama 30 hari. Pada penelitian ini bila persentase sel T CD4+ dibandingkan antara sebelum paparan dan setelah paparan medan elektromagnetik $1800 \mathrm{Mhz}$, maka tidak ada perubahan yang signifikan dari uji statistik pada persentase sel T CD4+ $(p=0,241)$ dan keduanya masih dalam range normal. Hal ini mungkin disebabkan paparan medan elektromagnetik dengan frekuensi $1800 \mathrm{Mhz}$ selama 60 menit masih dalam batas aman radiasi yang dapat diterima tubuh namun masih dibutuhkan penelitian lebih lanjut mengenai efek paparan jangka panjangnya. ${ }^{10}$

Berdasarkan hasil penelitian yang didapatkan, maka paparan medan elektromagnetik 1800 Mhz selama 60 menit tidak mempengaruhi persentase sel T CD4+ secara signifikan. Pada penelitian ini terdapat beberapa keterbatasan yaitu pemaparan hanya dilakukan dalam satu waktu, radikal bebas tidak diukur, serta penelitian dilakukan secara in vitro, bukan in vivo. 


\section{Kesimpulan}

Dari hasil di atas dapat disimpulkan tidak didapatkan perbedaan persentase sel $T$ CD4+ yang signifikan pada kultur PBMC individu sebelum paparan dan setelah pemaparan medan elektromagnetik frekuensi radio $1800 \mathrm{Mhz}$. Selain itu, frekuensi radio frekuensi $1800 \mathrm{Mhz}$ masih dalam batas aman untuk sel imun dan dapat diaplikasikan pada kegiatan sehari hari di masyarakat.

\section{Daftar Pustaka}

1. Rahmayani I. Indonesia Raksasa Teknologi Digital Asia. Sorotan Media Kominfo. (Online). 2015. https:// www.kominfo.go.id/content/detail/6095/ indonesia-raksasa-teknologi-digtalasia/0/ sorotan_media.

2. Alghamdi MS, El-Ghazaly AA. Effect of Exposure to Electromagnetic Field on some Hematological Parameters in Mice. Open Journal of Medical Chemistry. 2012; 2:30-42.

3. Territo M \& David G. Hemato and Oncology Lymphocytopenia. MSD Manual Profession Version. (Online). 2018. https:// www.msdmanuals.com/professional/ hematology-and-oncology/leukopenias/ lymphocytopenia.

4. Abbas AK, Lichtman AH, Pillai S. Imunologi Dasar Abbas: Fungsi dan Kelainan Sistem Imun. Edisi Ke-5.
Elsevier. 2016. P. 10-129.

5. Muir T. Peripheral Blood Mononuclear Cells: A Brief Review. (Online). 2019. https://www.stemexpress.com/blogs/ peripheral-blood-mononuclear-cells/. Diakses 3 November 2019.

6. Capri M, Salvioli S, Altilia S, Sevini F, Remondini D, Mesirca P, Bersani F, Monti D, Franceschi C. Age-Dependent Effects of In Vitro Radio Frequency Exposure (Mobile Phone) on CD95+ $T$ Helper Human Lymphocytes. Ann N Y Acad Sci. 2006; 067:493-9. doi: 10.1196/ annals.1354.071.

7. Rios AS, Fransisco AC, Jodefa L, Elisa $\mathrm{RM}$, Irene $\mathrm{C}$. Involvement of Free Radicals in Breast Cancer. Springerplus. 2013; 2:404. doi: 10.1186/2193-1801-2-404.

8. Gavrieli $Y$, Sherman $Y, \&$ Ben-Sasson SA. Identification of Programmed Cell Death In Situ Via Specific Labeling of Nuclear DNA Fragmentation. J Cell Biol. 1992; 119: 493-501.

9. Lamina S, Charles IE, Anele IT, Ezugwu UA. Effect of Free Redicals and Antioxidants on Exercise Performance. Oxidant and Antioxidant in Medical Science. 2013; 2(2):83-91. doi: 10.5455/ oams.010413.rv.005.

10. Husain $M$ \& Makiyah NN. Pengaruh Pajanan Gelombang Telepon Seluler terhadap Struktur Histologi Limpa pada Mencit (Mus musculus). Jurnal Kedokteran Yarsi. 2012; 20(3):167-173. 